\title{
PENGARUH PUPUK KANDANG DAN PUPUK HAYATI PADA PERTUMBUHAN DAN PRODUKSI TANAMAN TOMAT (Lycopersicum esculentum Mill.)
}

\section{THE EFFECT OF MANURE AND BIOLOGICAL FERTILIZER ON GROWTH AND PRODUCTION OF TOMATO (Lycopersicum esculentum Mill).}

\author{
Purba Sanjaya, Novi Kurnia, Kus Hendarto, \& Fitri Yelli \\ Jurusan Agroteknologi, Fakultas Pertanian, Universitas Lampung \\ J1 Sumantri Brojonegoro 1, Bandar Lampung 35145, Indonesia \\ *Email: purba.sanjaya@fp.unila.ac.id
}

\begin{abstract}
The Effect of Manure and Biological Fertilizer on Growth and Production of Tomato (Lycopersicum esculentum Mill). The productivity of tomato in Lampung Province has continued to decline in recent years. In 2017, the productivity of tomatoes was recorded at 13.46 tonnes/ha, while in 2019 it only reached 10.52 tonnes/ha. In fact, this value is still much lower than the national average of 18.63 tonnes/ha. To overcome this, increasing productivity is absolutely necessary, one of which is the addition of manure and biological fertilizer. This research was conducted at the Field Laboratory, Faculty of Agriculture, University of Lampung in January - May 2020. This study used a 4 x 3 factorial randomized block design (RBD) with three replications. The first factor is fertilization using several types of manure (chicken, goat and cow) as much as 1/3 of the planting medium, while the second factor is the application of biological fertilizers with doses of $0 \mathrm{l} / \mathrm{ha}, 4 \mathrm{l} / \mathrm{h}$ a, and $8 \mathrm{l} / \mathrm{ha}$. The results showed that the application of manure had a significant effect on all observation variables. From the three types of manure, goat manure gave the best results compared to other manure. The application of biological fertilizer at a dose of $4 \mathrm{l} / \mathrm{ha}$ had a significant effect on number of primary branches and the number of flowers of tomato and was the best treatment for biological fertilizers. There was no interaction between manure and biological fertilizer treatment.
\end{abstract}

Keywords: Biological fertilizer, manure, tomato.

\section{ABSTRAK}

Pengaruh Pupuk Kandang dan Pupuk Hayati Pada Pertumbuhan dan Produksi Tanaman Tomat (Lycopersicum esculentum Mill). Produktivitas tanaman tomat di Provinsi Lampung terus menurun dalam beberapa tahun terakhir. Pada Tahun 2017 tercatat produktivitas tomat mencapai 13.46 ton/ha, sedangkan pada tahun 2019 hanya mencapai 10.52 ton/ha. Bahkan nilai ini masih jauh lebih rendah dibandingkan dengan rata rata nasional yang mencapai 18.63 ton/ha. Untuk mengatasi hal tersebut peningkatan produktivitas mutlak dibutuhkan, salah satunya adalah dengan penambahan pupuk kandang dan pupuk hayati. Penelitian ini dilaksanakan di Laboratorium Lapang Terpadu, Fakultas Pertanian, Universitas Lampung pada bulan Januari - Mei 2020. Penelitian ini menggunakan Rancangan Acak Kelompok (RAK) secara faktorial 4 x 3 dengan tiga ulangan. Faktor pertama adalah pemupukan dengan menggunakan beberapa jenis pupuk kandang (ayam, kambing dan sapi) sebanyak 
1/3 bagian media tanam, sedangkan faktor kedua adalah aplikasi pupuk hayati dengan dosis, $01 /$ ha, $41 /$ ha, dan $81 /$ ha. Hasil penelitian menunjukkan bahwa aplikasi pupuk kandang berpengaruh nyata terhadap seluruh variabel pengamatan. Dari ketiga jenis pupuk kandang, pupuk kandang kambing memberikan hasil yang paling baik dibandingkan pupuk kandang lainnya. Aplikasi pupuk hayati dengan dosis 4 1/ha berpengaruh nyata terhadap variabel jumlah cabang primer dan jumlah bunga tanaman tomat dan merupakan perlakuan terbaik untuk pupuk hayati. Tidak terjadi interaksi antara perlakuan pupuk kandang dan pupuk hayati.

Kata kunci: Pupuk hayati, pupuk kandang, tomat.

\section{PENDAHULUAN}

Tanaman tomat (Lycopersicum esculentum Mill.) merupakan salah satu jenis sayuran penting di Indonesia. Saat ini kebutuhan di Indonesia tomat belum dapat diimbangi dengan jumlah produksi karena rendahnya produktivitas. Produktivitas tanaman tomat terus menurun dalam beberapa tahun terakhir di Provinsi Lampung. Pada Tahun 2017 tercatat produktivitas tomat mencapai 13.46 ton/ha, sedangkan pada tahun 2019 hanya mencapai 10.52 ton/ha. Nilai ini masih jauh lebih rendah dibandingkan dengan rata rata nasional yang mencapai 18.63 ton/ha (Badan Pusat Statistik dan Direktorat Jenderal Hortikultura, 2020). Salah satu penyebab rendahnya produktivitas ini adalah penggunaan pupuk sintetis secara terus menerus tanpa tambahan pupuk organik. Menurut Notohadiprawiro (2006), penggunaan pupuk sintetis secara intensif dan terus menerus dapat mengakibatkan pengerasan tanah yang disebabkan oleh penumpukan sisa pupuk buatan sehingga tanah sulit terurai. Tanah yang keras menghasilkan beberapa dampak negatif diantaranya: 1). Tanaman semakin sulit menyerap unsur hara, 2). Pemakaian dosis pupuk yang lebih tinggi untuk mendapatkan hasil sama dengan hasil panen sebelumnya, 3). Sistem perakaran terganggu sehingga fungsi akarkurang optimal. Tujuan penelitian ini adalah untuk mengetahui pengaruh dari pupuk kandang dan pupuk hayati pada pertumbuhan dan hasil produksi tanaman tomat (Lycopersicum esculentum Mill.).

\section{BAHAN DAN METODE}

Penelitian ini dilaksanakan di Laboratorium Lapang Terpadu Fakultas Pertanian Universitas Lampung. Penelitian dimulai pada bulan Januari 2020 - Mei 2020. Alat yang digunakan pada penelitian ini adalah polibag, cangkul, ajir bambu, tali raffia, gunting, pisau, gayung, ember, meteran, timbangan analitik, gelas ukur, penggaris dan alat tulis. Bahan yang digunakan pada penelitian ini adalah benih Tomat Permata F1, pupuk kandang dari kotoran ayam, kotoran sapi, kotoran kambing, pupuk hayati dengan merk dagang Grikulan Plus, pupuk dasar (NPK), tanah, sekam, air, fungisida Dithane, insektisida Furadan 3GR dan insektisida Decis.

Penelitian ini dilakukan dengan menggunakan Rancangan Acak Kelompok (RAK) yang disusun secara faktorial $4 \times 3$ dengan tiga ulangan. Faktor pertama adalah pemupukan dengan menggunakan beberapa jenis pupuk kandang $(\mathrm{P})$, terdiri dari tanpa pupuk kandang/kontrol (P0), pupuk kandang dari kotoran ayam (P1), pupuk kandang dari kotoran kambing (P2), pupuk kandang dari kotoran sapi (P3). 
Faktor kedua adalah aplikasi pupuk hayati Grikulan Plus $(\mathrm{H})$ dengan berbagai tingkat dosis, yang terdiri dari aplikasi pupuk hayati dosis $01 /$ ha (H0), dosis $41 /$ ha $(\mathrm{H} 1)$, dosis $81 /$ ha $(\mathrm{H} 2)$. Hasil analisis ragam yang nyata dilakukan uji lanjut menggunakan Uji Beda Nyata Terkecil (BNT) pada taraf 5\%.

\section{HASIL DAN PEMBAHASAN}

Berdasarkan hasil rekapitulasi hasil analisis ragam (Tabel 1), dapat diketahui bahwa perlakuan pupuk kandang berpengaruh nyata pada seluruh variabel yang diamati, yaitu tinggi tanaman pada $8 \mathrm{MST}$, jumlah cabang primer pada $8 \mathrm{MST}$, jumlah bunga per tanaman, jumlah buah panen per tanaman, bobot buah per tanaman dan volume buah per tanaman. Perlakuan pupuk hayati hanya berpengaruh nyata pada jumlah cabang primer $8 \mathrm{MST}$, dan jumlah bunga per tanaman, sedangkan interaksi dari kedua perlakuan tersebut tidak memberikan pengaruh yang signifikan terhadap seluruh variabel pengamatan.

Berdasarkan hasil uji lanjut BNT pada taraf $5 \%$, terlihat bahwa pupuk kandang kambing secara signifikan meningkatkan hasil pengukuran seluruh variabel yang diamati (Tabel 2 hingga Tabel 7). Terdapat beberapa faktor yang memungkinkan hal ini dapat terjadi. Faktor pertama yaitu perbedaan sifat fisik pupuk kandang kambing dari pupuk kandang lainnya. Pupuk kandang kambing memiliki bentuk fisik bulat dan kasar sedangkan pupuk kandang ayam dan pupuk kandang sapi memiliki tekstur pupuk berbentuk butiran halus.

Tabel 1. Rekapitulasi hasil analisis ragam pengaruh pupuk kendang dan pupuk hayati serta interaksinya pada beberapa variabel pengamatan.

\begin{tabular}{lcccc}
\hline \multirow{2}{*}{ Variabel Pengamatan } & \multicolumn{2}{c}{ Perlakuan } & & \\
\cline { 2 - 3 } & Pupuk Kandang & Pupuk & Interaksi & Kelompok \\
& & Hayati & & \\
\hline Tinggi tanaman (cm) 8 MST & $* *$ & tn & tn & $* *$ \\
Jumlah cabang primer 8 MST & $* *$ & $* *$ & tn & $*$ \\
Jumlah bunga per tanaman & $*$ & tn & tn & tn \\
Jumlah buah panen per tanaman & $*$ & tn & tn & tn \\
Bobot buah per tanaman $(\mathrm{g})$ & $*$ & tn & tn & tn \\
Volume buah per tanaman $(\mathrm{ml})$ & & & & \\
\hline
\end{tabular}

Keterangan : $*$ = nyata pada taraf $5 \%$; tn $=$ tidak berbeda nyata

Tabel 2. Pengaruh pupuk kandang terhadap variabel tinggi tanaman tomat 8 MST

\begin{tabular}{lc}
\hline \multicolumn{1}{c}{ Perlakuan } & Tinggi Tanaman $(\mathrm{cm})$ \\
\hline Tanpa pupuk kandang (P0) & $83.41 \mathrm{~b}$ \\
Pupuk kandang ayam (P1) & $98.98 \mathrm{a}$ \\
Pupuk kandang kambing (P2) & $106.39 \mathrm{a}$ \\
Pupuk kandang sapi (P3) & $97.20 \mathrm{a}$ \\
\hline BNT 5\% & 9.60 \\
\hline
\end{tabular}

Keterangan : Angka yang diikuti oleh huruf yang sama tidak berbeda nyata berdasarkan uji BNT 5\% 
Tabel 3. Pengaruh pupuk kandang dan pupuk hayati terhadap variabel jumlah cabang primer tanaman tomat 8 MST.

\begin{tabular}{lc}
\hline \multicolumn{1}{c}{ Perlakuan } & Jumlah Cabang Primer \\
\hline Tanpa pupuk kandang (P0) & $18.52 \mathrm{~b}$ \\
Pupuk kandang ayam (P1) & $21.37 \mathrm{a}$ \\
Pupuk kandang kambing (P2) & $22.89 \mathrm{a}$ \\
Pupuk kandang sapi (P3) & $21.70 \mathrm{a}$ \\
\hline BNT 5\% & 2.14 \\
\hline Pupuk hayati 0 1/ha & $19.17 \mathrm{~b}$ \\
Pupuk hayati 4 1/ha & $22.81 \mathrm{a}$ \\
Pupuk hayati 8 1/ha & $21.39 \mathrm{ab}$ \\
\hline BNT 5\% & 2.47 \\
\hline
\end{tabular}

Keterangan : Angka yang diikuti oleh huruf yang sama tidak berbeda nyata berdasarkan uji BNT 5\%

Tabel 4. Pengaruh pupuk kandang terhadap jumlah bunga per tanaman tomat

\begin{tabular}{lc}
\hline \multicolumn{1}{c}{ Perlakuan } & Jumlah Bunga per Tanaman \\
\hline Tanpa pupuk kandang (P0) & $21.39 \mathrm{~b}$ \\
Pupuk kandang ayam (P1) & $19.74 \mathrm{~b}$ \\
Pupuk kandang kambing (P2) & $29.57 \mathrm{a}$ \\
Pupuk kandang sapi (P3) & $22.28 \mathrm{~b}$ \\
\hline BNT 5\% & 3.57 \\
\hline Pupuk hayati 0 1/ha & $23.24 \mathrm{ab}$ \\
Pupuk hayati 4 1/ha & $25.79 \mathrm{a}$ \\
Pupuk hayati 8 1/ha & $20.71 \mathrm{~b}$ \\
\hline BNT 5\% & 4.13 \\
\hline
\end{tabular}

Keterangan : Angka yang diikuti oleh huruf yang sama tidak berbeda nyata berdasarkan uji BNT 5\%

Hal ini diduga akan berpengaruh pada porositas dan aerasi tanah yang lebih baik. Kemampuan media tanam dalam menunjang pertumbuhan akar yang baik tergantung pada distribusi ukuran pori-pori tanah. Semakin banyak pori-pori tanah maka porositas akan semakin tinggi dan semakin baik media tanam. Hal ini menjadi pertimbangan penulis terutama karena tingginya curah hujan yang terjadi pada saat penelitian. Awal penelitian dilaksanakan pada bulan Januari dan Februari bersamaan dengan puncak curah hujan tahunan. Pada saat curah hujan tinggi, porositas dan aerasi pupuk kandang kambing lebih baik dibandingkan pupuk kandang ayam dan sapi yang menjadi macak macak dan jenuh air ketika terlalu banyak menyerap air.

Secara kimiawi pupuk kandang kambing mengandung kalium $(\mathrm{K})$ yang relatif lebih tinggi dari pupuk kandang lainnya, sementara kadar hara $\mathrm{N}$ dan P hampir sama dengan pupuk kandang lainnya (Hartatik dan Widowati, 2006). Unsur hara kalium (K) berfungsi untuk pengangkutan karbohidrat, sebagai katalisator dalam pembentukan protein, meningkatkan kadar karbohidrat dan gula dalam buah, membuat biji tanaman menjadi lebih berisi dan padat, meningkatkan kualitas buah seperti bentuk dan warna lebih baik, 
Tabel 5. Pengaruh pupuk kandang terhadap jumlah buah panen tanaman tomat

\begin{tabular}{lc}
\hline \multicolumn{1}{c}{ Perlakuan } & Jumlah Buah Panen \\
\hline Tanpa pupuk kandang (P0) & $16.50 \mathrm{~b}$ \\
Pupuk kandang ayam (P1) & $17.76 \mathrm{~b}$ \\
Pupuk kandang kambing (P2) & $25.02 \mathrm{a}$ \\
Pupuk kandang sapi (P3) & $17.13 \mathrm{~b}$ \\
\hline BNT 5\% & 5.01 \\
\hline
\end{tabular}

Keterangan : Angka yang diikuti oleh huruf yang sama tidak berbeda nyata berdasarkan uji BNT 5\%

Tabel 6. Pengaruh pupuk kandang terhadap bobot buah tomat per tanaman

\begin{tabular}{lc}
\hline \multicolumn{1}{c}{ Perlakuan } & Bobot Buah per Tanaman (g) \\
\hline Tanpa pupuk kandang (P0) & $467.69 \mathrm{~b}$ \\
Pupuk kandang ayam (P1) & $461.82 \mathrm{~b}$ \\
Pupuk kandang kambing (P2) & $638.09 \mathrm{a}$ \\
Pupuk kandang sapi (P3) & $517.94 \mathrm{ab}$ \\
\hline BNT 5\% & 157.68 \\
\hline
\end{tabular}

Keterangan : Angka yang diikuti oleh huruf yang sama tidak berbeda nyata berdasarkan uji BNT 5\%

Tabel 7. Pengaruh pupuk kandang terhadap volume buah tomat per tanaman

\begin{tabular}{lc}
\hline \multicolumn{1}{c}{ Perlakuan } & Volume Buah per Tanaman (ml) \\
\hline Tanpa pupuk kandang (P0) & $462.87 \mathrm{~b}$ \\
Pupuk kandang ayam (P1) & $478.15 \mathrm{~b}$ \\
Pupuk kandang kambing (P2) & $719.72 \mathrm{a}$ \\
Pupuk kandang sapi (P3) & $528.24 \mathrm{~b}$ \\
\hline BNT 5\% & 147.70 \\
\hline
\end{tabular}

Keterangan : Angka yang diikuti oleh huruf yang sama tidak berbeda nyata berdasarkan uji BNT 5\%

meningkatkan daya tahan terhadap kekeringan dan penyakit, selain itu juga berperan dalam perkembangan akar (Wardhani et al., 2014). Selain itu, menurut Hardjowigeno (2003), peranan unsur K bagi tanaman sangat penting dalam setiap proses melabolisme tanaman yaitu sintesis asam amino dan protein dari ionion ammonium dalam proses fotosintesis, kekurangan kalium dalam daun akan menurunkan kecepatan asimilasi karbon dioksida $\left(\mathrm{CO}_{2}\right)$. Selain unsur kalium (K), pupuk kandang kambing mengandung unsur kalsium $(\mathrm{Ca})$ sebesar $1.64 \%$ lebih tinggi daripada yang terkandung pada pupuk kandang sapi (1.04\%) dan ayam (1.57\%) (Semekto, 2006).

Berbeda dengan pupuk kandang, pupuk hayati hanya berpengaruh nyata pada variabel jumlah cabang primer tanaman tomat $8 \mathrm{MST}$ dan jumlah bunga tomat per tanaman. Perlakuan pupuk hayati dengan dosis 4 1/ha secara signifikan meningkatkan cabang primer dan jumlah bunga tomat. Kedua variabel ini menunjukkan mikro organisme pengurai yang diberikan tetap 
berkembang dan efektifdalam mengurai bahan organik di media tanam hingga 8 MST. Bahan organik yang terus menerus di rombak oleh terus menyediakan unsur hara terus menerus secara slow release dan terus tersedia hingga akhir fase pertumbuhan tanaman. Hal ini jugalah yang menyebabkan kedua variabel pengamatan ini justru menjadi nyata di akhir fase pertumbuhan tanaman.

\section{KESIMPULAN}

Aplikasi pupuk kandang berpengaruh nyata terhadap seluruh variabel pengamatan, dari ketiga jenis pupuk kandang, pupuk kandang kambing memberikan hasil yang paling baik dibandingkan pupuk kandang lainnya. Aplikasi pupuk hayati dengan dosis 4 1/ha berpengaruh nyata terhadap variabel jumlah cabang primer dan jumlah bunga tanaman tomat dan merupakan perlakuan terbaik untuk pupuk hayati. Tidak terjadi interaksi antara perlakuan pupuk kandang dan pupuk hayati.

\section{DAFTAR PUSTAKA}

Badan Pusat Statistik dan Direktorat Jenderal Hortikultura. 2020. Produktivitas Tomat Menurut Provinsi, Tahun 2015-2019. Diakses 20 Desember 2020. https://www.pertanian. go.id/home/?show=page\&act=view\&id=61.

Hardjowigeno S, 2003. Ilmu Tanah. Jakarta: Akademika Pressindo.

Notohadiprawiro, T. 2006. Ultisol, Fakta dan Implikasi Pertaniannya. Ilmu tanah Universitas Gadjah Mada. Yogyakarta.

Samekto. R. 2006. Pupuk Kandang. PT. Citra Aji Parama. Yogyakarta.

Wardhani, S., Purwani, K. I., dan Anugerahani,W. (2014). Pengaruh Aplikasi Pupuk Hayati terhadap Pertumbuhan dan Produktivitas Tanaman Cabai Rawit (Capsicum frutescens L.) Varietas Bhaskara di PT Petrokimia Gresik. Jurnal Sains dan Seni Pomits Vol. 2 No.1.

Wiwik Hartatik dan L.R. Widowati, 2006. Pupuk Kandang. dalam Pupuk Organik dan Pupuk Hayati. Balai Besar Litbang Sumberdaya Lahan Pertanian Badan Penelitian dan Pengembangan Pertanian. Jawa Barat. $64 \mathrm{hlm}$. 